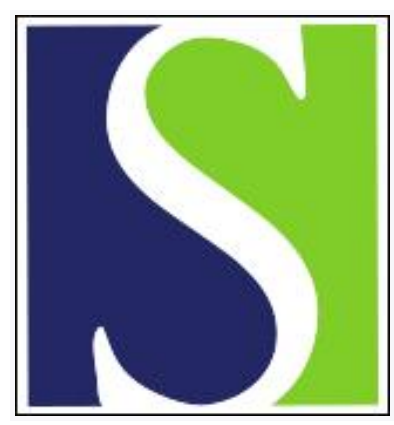

Scand J Work Environ Health 1987;13(5):453-458

https://doi.org/10.5271/sjweh.2015

Issue date: Oct 1987

Effects of low-dose inhalation of three chlorinated aliphatic organic solvents on deoxyribonucleic acid in gerbil brain.

by Karlsson JE, Rosengren LE, Kjellstrand P, Haglid KG

Affiliation: Institute of Neurobiology, University of Goteborg, Sweden.

This article in PubMed: www.ncbi.nlm.nih.gov/pubmed/3433047 


\title{
Effects of low-dose inhalation of three chlorinated aliphatic organic solvents on deoxyribonucleic acid in gerbil brain
}

\author{
by Jan-Erik Karlsson MD, BS, ${ }^{1}$ Lars E Rosengren MD, ${ }^{1}$ Per Kjellstrand $\mathrm{PhD},{ }^{2}$ Kenneth G Haglid MD ${ }^{1}$
}

\begin{abstract}
KARLSSON J-E, ROSENGREN LE, KJELLSTRAND P, HAGLID KG. Effects of low-dose inhalation of three chlorinated aliphatic organic solvents on deoxyribonucleic acid in gerbil brain. Scand $J$ Work Environ Health 13 (1987) 453-458. Young adult Mongolian gerbils (Meriones ungiculatus) were continuously exposed by inhalation to 1,1,1-trichloroethane at the Swedish occupational exposure limit (70 $\mathrm{ppm})$, to methylene chloride at three times $(210 \mathrm{ppm})$ the Swedish occupational exposure limit $(70 \mathrm{ppm})$, and to perchloroethylene at three times $(60 \mathrm{ppm})$ the Swedish occupational exposure limit (20 ppm), for three months, followed by a four-month postexposure solvent-free period. The concentrations of deoxyribonucleic acid (DNA) were then determined in different regions of the gerbil central nervous system. It was observed that the DNA concentrations in several brain regions were decreased in the exposed animals. It was found that 1,1,1-trichloroethane induced these alterations in many more brain areas at its Swedish occupational exposure limit than the other solvents studied at threefold their Swedish occupational exposure limits. The results suggest that all the solvents decrease cell density by inhibiting the slow acquisition of DNA or by inducing cell death in some sensitive brain areas and that 1,1,1-trichloroethane should not be regarded as harmless as previously stated.
\end{abstract}

Key terms: brain, chronic inhalation, deoxyribonucleic acid, gerbil, methylene chloride, perchloroethylene, total protein, 1,1,1-trichloroethane.

1,1,1-Trichloroethane (methylchloroform), methylene chloride (dichloromethane), and perchloroethylene (tetrachloroethylene) are chlorinated hydrocarbons that are widely used in industrial and consumer products. 1,1,1-Trichloroethane has become increasingly popular during the last few decades because of its reputed low degree of toxicity (37). However, little is known of the neurotoxicity of the compound. Studies on workers in occupational settings have been made, but no adverse effects on the central nervous system have been observed after chronic exposure to 1,1,1trichloroethane $(12,17,18)$; however, the exposure levels in these studies were relatively low. Acute exposure of humans to 1,1,1-trichloroethane at $350 \mathrm{ppm}$ has been shown to impair functions of the central nervous system in some individuals (7). Lightheadedness, headache and coordination problems, drowsiness, anesthesia, narcosis, and even death may occur as a consequence of accidental human exposure to high solvent concentrations $(4,22,33,36)$. A few long-term studies on animals have been performed, and 1,1,1trichloroethane has been reported to be well tolerated in several different species after long-term exposures at different solvent concentrations $(5,22,23)$.

The adverse effects associated with exposure to methylene chloride are primarily neurological and

\footnotetext{
Institute of Neurobiology, University of Göteborg, Göteborg, Sweden.

2 Institute of Zoophysiology, University of Lund, Lund, Sweden.
}

Reprint requests to: Dr KG Haglid, Institute of Neurobiology, University of Göteborg, PO Box 33 031, S-400 33 Göteborg, Sweden. cardiovascular $(35,38)$. Central nervous system effects are related to the anesthetic properties of the solvent, and exposure of humans to the solvent at 500-1000 ppm has been shown to cause early signs of central nervous system depression $(35,42)$. In the occupational setting diffuse toxic brain damage, resulting in visual and auditory illusions, has been reported after chronic exposure to methylene chloride $(39,40)$. Bilateral temporal lobe degeneration has been described in one individual after long-term exposure to high concentrations of the solvent (2).

The adverse effects associated with exposure to perchloroethylene primarily involve the central nervous system. Exposure of humans to low levels of this solvent $(100 \mathrm{ppm})$ has been shown to result in signs of central nervous system depression in some individuals (34), and it is aggravated at higher concentrations (28). Central nervous system symptoms, characteristic of the neurasthenic syndrome, have been described after chronic exposure to high concentrations of perchloroethylene (8).

The purpose of this study was to compare the effects of chronic exposure to 1,1,1-trichloroethane, methylene chloride, and perchloroethylene at low levels on the cell density of different distinct brain areas of the gerbil central nervous system. The gerbils were exposed by continuous inhalation to 1,1,1-trichloroethane at $70 \mathrm{ppm}$, to methylene chloride at $210 \mathrm{ppm}$, and to perchloroethylene at $60 \mathrm{ppm}$ for three months, followed by a post-exposure solvent-free period of four months. After this period the deoxyribonucleic acid (DNA) concentrations were quantitatively analyzed as a measure of cell content in the various brain areas. 


\section{Materials and methods}

Animals

Twenty-four male and 24 female Mongolian gerbils (Meriones ungiculatus) were used. The initial mean weight of the male gerbils was 63.9 (SE 1.2) $\mathrm{g}$ and of the females 50.9 (SE 0.8) g. The male and female animals were housed separately in transparent plastic cages $(45 \times 24 \times 15 \mathrm{~cm}$, four in each). The experimental and control animals were sex-matched littermates. Commercial laboratory rat chow (Astra Ewos, Sweden) and water was freely available. Sawdust was used as bedding. The environmental temperature was kept at $22 \pm 2^{\circ} \mathrm{C}$. Light supplementing daylight was automatically controlled for $12 \mathrm{~h}$ of daylight, with $30 \mathrm{~min}$ of twilight at dawn and evening.

\section{Exposure}

During the experimental run, the exposure was continuous. Commercial 1,1,1-trichloroethane, containing $5 \%$ dioxane-free stabilizers (methyl ethyl ketone, methylene oxide, butylene epoxide, butanol, and nitromethane), methylene chloride, containing $0.3-$ $0.5 \%$ stabilizers (butylene oxide and antioxidants), and tetrachloroethylene, containing $0.01 \%$ stabilizers, all of cleaning grade, were used (Billerud AB, Sweden). Each solvent was injected into a temperature-controlled glass-vaporizer $\left(60^{\circ} \mathrm{C}\right)$, mixed with a small volume of air $(20 \mathrm{l} / \mathrm{h})$, and then diluted with clean air $(1000 \mathrm{l} / \mathrm{h})$ to produce the desired concentration $(70 \mathrm{ppm}$ for $1,1,1$ trichloroethane, $210 \mathrm{ppm}$ for methylene chloride, and $60 \mathrm{ppm}$ for perchloroethylene). All air was filtered to remove oil and particles larger than $0.3 \mu \mathrm{m}$. The concentration in the inhalation chambers was monitored with a Miran 1A spectrophotometer fitted with a multipath gas cell. The long-term stability of the system permitted the concentration of the solvent to be held within $10 \%$ of the decided concentration. Interruptions occurred only $1-2 \mathrm{~h}$ per week for the changing of water, bedding material, and food.

Four male and four female gerbils were exposed for each solvent concentration. Eight sex-matched littermates served as controls for each solvent concentration and were exposed to clean air $(1000 \mathrm{l} / \mathrm{min})$ in chambers identical to those of the experimental animals. The exposure period was three months. Subsequently, the animals were removed from the inhalation chambers and kept free from exposure for a fourmonth period.

\section{Preparation of tissue}

After the solvent-free period, the gerbils were killed. The brains were removed from the skulls and separated from the spinal cords by transection at the distal end of the fourth ventricle. The olfactory bulbs were removed, and the brains were weighed. The cerebral cortices were dissected on ice and divided by transverse cuts into three equally long parts, ie, frontal (frontal), middle (sensory-motor), and dorsal (occipital) cerebral cortex. The cerebellar hemispheres were divided at the position of the sulci intercrurales into anterior and posterior parts. The anterior (lobuli $\mathrm{I}-\mathrm{V}$ ) and posterior (lobuli VI-X) cerebellar vermis, as well as the brain stem (under the fourth ventricle) and the hippocampus, were also dissected. Tissue samples were weighed, quickly frozen on dry ice, and then stored in tightfitting boxes at $-80^{\circ} \mathrm{C}$ until analyzed. Tissues were homogenized at $1: 5$ or $1: 20$ (weight: volume) in 0.024 $\mathrm{M}$ barbital buffer, $\mathrm{pH} 8.6$, with $2.5 \mathrm{mM}$ ethylene diaminetetraacetic acid and $1.0 \mathrm{mM}$ 2-mercaptoethanol.

\section{Analytical procedure}

The protein concentrations in the homogenates were determined according to Lowry et al (14). Bovine serum albumin was used as the reference standard. Analyses of the DNA concentrations in the homogenates were carried out according to Kissane \& Robins (10). Salmon DNA was used as the reference standard.

\section{Statistical evaluation}

The nonparametric Fisher's permutation test for paired observations was used to test the differences observed between the control and the exposed groups (1).

\section{Results}

\section{Body and brain weights}

No animal died during the exposure or the solvent-free periods. There were no significant differences in body weight between the exposed and control animals, either at the end of exposure or after the solvent-free period. Brain weights and the weights of the dissected brain regions were not significantly altered between the exposed and control animals.

\section{Protein and deoxyribonucleic acid concentrations}

I,I,I-Trichloroethane. The total protein concentrations per wet weight in the different brain regions studied were not significantly different after exposure to $1,1,1$ trichloroethane at $70 \mathrm{ppm}$. However, the DNA concentrations were significantly lower in the exposed animals in three different brain areas, ie, the posterior cerebellar hemisphere, the anterior cerebellar vermis, and the hippocampus (figure 1).

Methylene chloride. The total protein concentrations per wet weight in the different brain regions studied were not significantly changed after exposure to methylene chloride at $210 \mathrm{ppm}$, when compared to those of the controls. The DNA concentrations per wet weight were significantly decreased in the hippocampus after the exposure (figure 2). 


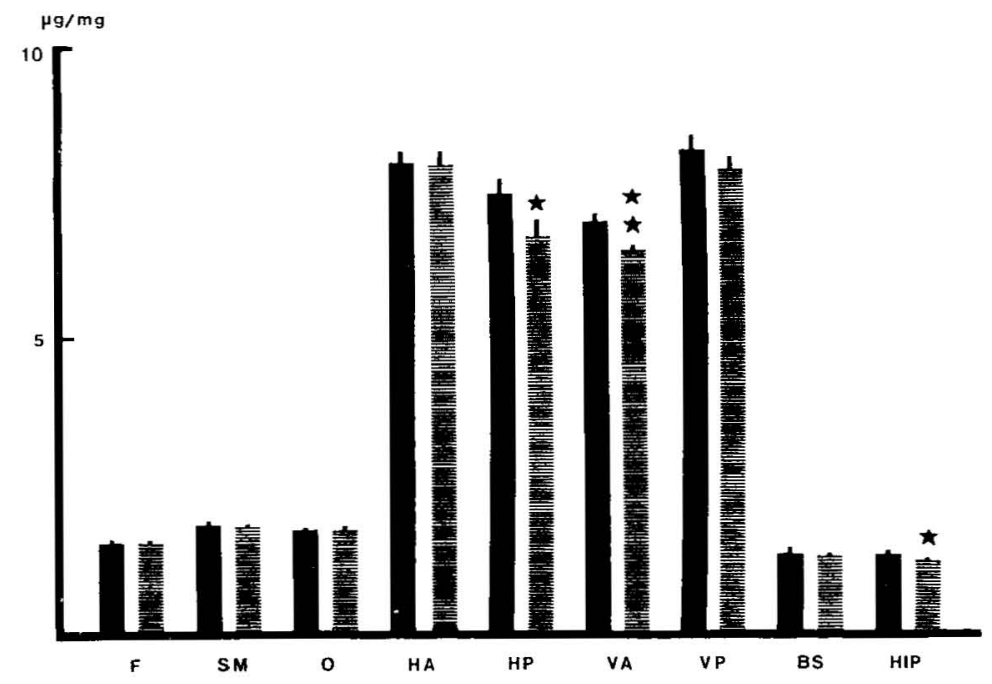

Figure 1. Deoxyribonucleic acid concentrations per wet weight $(\mu \mathrm{g} / \mathrm{mg})$ in gerbil brain areas after exposure to 1,1,1-trichloromethane at $70 \mathrm{ppm}$ for three months followed by a postexposure solvent-free period of four months. The statistical evaluation was performed with the Fisher's permutation test for paired observations $\left({ }^{*} P \leq 0.05\right)$. ( $F=$ frontal cerebral cortex, $\mathrm{SM}=$ sensory-motor cerebral cortex, $\mathrm{O}=$ occipital cerebral cortex, $\mathrm{HA}=$ anterior cerebellar hemispheres, $\mathrm{HP}=$ posterior cerebellar hemispheres, $\mathrm{VA}=$ anterior cerebellar vermis, $\mathrm{VP}=$ posterior cerebellar vermis, $\mathrm{BS}=$ brain stem, $\mathrm{HIP}=$ hippocampus, bars = mean values of eight animals and the standard errors of the means, black columns = values for control animals, striped columns = values for exposed animals)

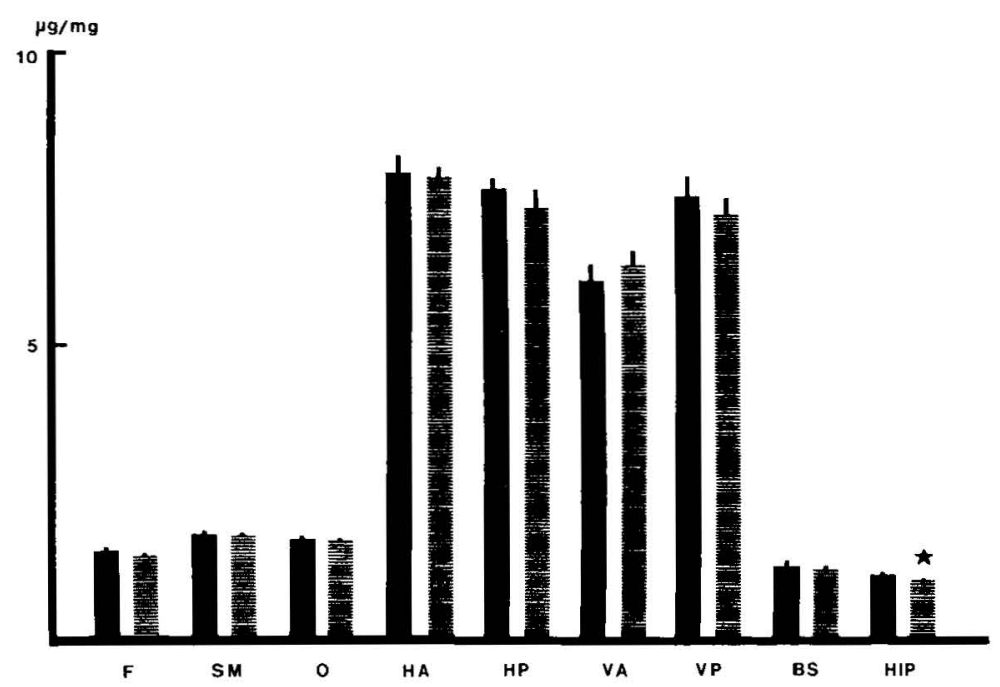

Figure 2. Deoxyribonucleic acid concentrations per wet weight $(\mu \mathrm{g} / \mathrm{mg})$ in gerbil brain areas after exposure to methylene chloride at $210 \mathrm{ppm}$ for three months followed by a postexposure solvent-free period of four months. The statistical evaluation was performed with the Fisher's permutation test for paired observations $\left({ }^{*} P \leq 0.05\right)$. The studied brain areas as described in figure 1. (Bars = mean values of eight animals and the standard errors of the means, black columns = values for control animals, striped columns = values for exposed animals)

Perchloroethylene. The total protein concentrations per wet weight in the different brain areas studied were not significantly changed after exposure to perchloroethylene at $60 \mathrm{ppm}$. The DNA concentrations per wet weight were decreased in the frontal cerebral cortex after the exposure (figure 3 ).

\section{Discussion}

In this study, gerbils were exposed either to $1,1,1$ trichloroethane at the Swedish occupational exposure limit $(70 \mathrm{ppm})$ or to methylene chloride at three times $(210 \mathrm{ppm})$ the occupational exposure limit $(70 \mathrm{ppm})$ 


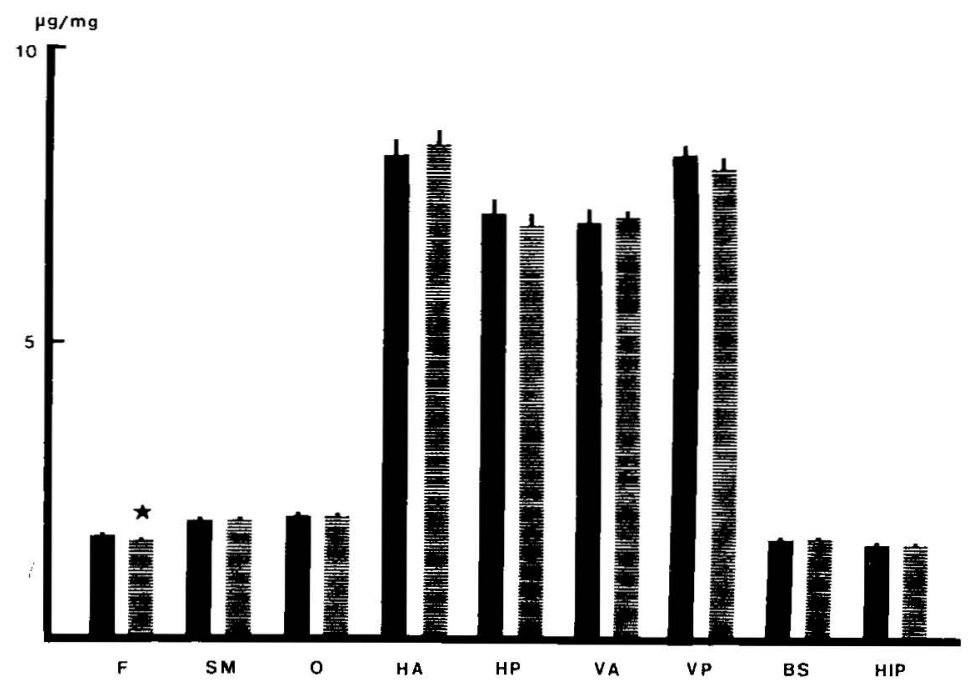

Figure 3. Deoxyribonucleic acid concentrations per wet weight $(\mu \mathrm{g} / \mathrm{mg})$ in gerbil brain areas after exposure to perchloroethylene at $60 \mathrm{ppm}$ for three months followed by a postexposure solvent-free period of four months. The statistical evaluation was performed with the Fisher's permutation test for paired observations $\left({ }^{*} P \leq 0.05\right)$. The studied brain areas as described in figure 1 . (Bars = mean values of eight animals and the standard errors of the means, black columns = values for control animals, striped columns = values for exposed animals)

or to perchloroethylene at three times $(60 \mathrm{ppm})$ the occupational exposure limit ( $20 \mathrm{ppm})$ by continuous inhalation for three months. Previous experiments with ethanol, perchloroethylene, methylene chloride, and xylene confirm that this period of time is sufficient to induce alterations among different cell populations in gerbil brain (24-27). According to these studies, the animals were subjected to a postexposure, solvent-free period of four months to permit an estimation of the lasting or permanent changes induced by the preceding exposure.

In this study no significant changes in body or brain weights were found between the exposed and control animals. The concentrations of total proteins in the different brain areas were not significantly affected by the exposure. However, exposure to 1,1,1-trichloroethane at the Swedish occupational exposure limit (70 $\mathrm{ppm}$ ) induced lasting decreased DNA concentrations in three brain areas, ie, the posterior cerebellar hemisphere, the anterior cerebellar vermis, and the hippocampus, while exposure to methylene chloride and perchloroethylene at three times $(210$ or $60 \mathrm{ppm})$ their Swedish occupational exposure limits resulted in decreased DNA levels in the hippocampus and frontal cerebral cortex, respectively. On the assumption of a diploid DNA content in the brain cells and a metabolic stability of DNA in the adult brain $(9,15)$, our results indicate a decreased cell density in several different brain regions that may be due to a loss of cells. This phenomenon might be ascribed to cell death of eg, nerve or oligodendroglial cells, or the inhibition of the slow nonneuronal cell acquisition phase in the adult brain (11). Cellular events occurring during changes of the normal environment of brain cells, especially with regard to neurotoxins, are complex. Our results demonstrate, far beyond chance, that long-term exposure to these solvents results in altered DNA concentrations as a sign of neurotoxicity in different parts of the gerbil brain. Although the mechanism behind the neurotoxicity of these solvents is unknown, our results clearly show that no correlation between the respective Swedish occupational exposure limits and their effects could be determined.

1,1,1-Trichloroethane is metabolized to a negligible extent $(30,31)$, contrary to methylene chloride $(3,13)$, while perchloroethylene is metabolized to some extent $(21,32)$. Thus local biotransformation of the solvents in the central nervous system could not explain why 1,1,1-trichloroethane seems to have greater effects than methylene chloride and perchloroethylene. However, in this context, one has to consider that the central nervous system contains a low content of the cytochrome P-450-monoxygenase system (16) and that the brain levels of reactive metabolites might be low. With regard to methylene chloride, the glutathione-dependent pathway of biotransformation present in the brain has to be considered (1), as well as the fact that methylene chloride-derived ${ }^{14}$ carbon activity in brain macromolecules has been demonstrated, and this phenomenon might reflect metabolite binding $(19,20)$. On the other hand, as 1,1,1-trichloroethane is very lipid soluble (29) and as high concentrations of the solvent can reach the central nervous system during exposure (4I), effects on brain membranes are probable. However, perchloroethylene is approximately five times more lipid soluble than 1,1,1-trichloroethane and should reach even higher levels in the central nervous system (6). Lipid solubility could thus not explain our results. The biochemical alterations induced after chronic low-level exposure to 1,1,1-trichloroethane in- 
dicates that this solvent cannot be regarded as harmless, as previously stated (37), in comparison to methylene chloride and perchloroethylene.

\section{Acknowledgments}

This work has been supported by the Swedish Work Environment Fund (ASF 83-0810, ASF 84-0217, and ASF 85-0585). Ms E Åwall's skillful technical assistance is gratefully acknowledged, as is the statistical advice of Mr L Trulsson, Göteborgs Datacentral.

\section{References}

1. Ahmed AE, Anders MW. Metabolism of dihalomethanes to formaldehyde and inorganic halide: I In vitro studies. Drug Metab Dispos 4 (1976) 357-361.

2. Barrowcliff DF, Knell AJ. Cerebral damage due to endogenous chronic carbon monoxide poisoning caused by exposure to methylene chloride. Soc Occup Med 29 (1979) 12-14.

3. Bradley JV. Distribution-free statistical tests. PrenticeHall, Inc, Englewood Cliffs, NJ 1968.

4. Dornette WHL, Jones JP. Clinical experiences with 1,1,1-trichloroethane: A preliminary report of 50 anesthetic administrations. Anesth Analg (Cleveland) 39 (1960) 249-253.

5. Eben A, Kimmerle G. Metabolism, excretion and toxicology of methylchloroform in acute and subacute exposed rats. Arch Toxicol 31 (1974) 233-242.

6. Fiserova-Bergerova V. Modeling of inhalation exposure to vapors: Uptake, distribution, and elimination. Volume 1. CRC Press Inc, Boca Raton, FL 1983.

7. Gamberale F, Hultengren M. Methylchloroform exposure: II Psychophysiological functions. Work Environ Health $10(1973) 82-92$.

8. Gold JH. Chronic perchioroethylene poisoning. Can Psychiatr Assoc J 14 (1969) 627-630.

9. Hobi R, Studer M, Ruch F, Kuenzle CC. The DNA content of cerebral cortex neurons: Determinations by cytophotometry and high performance liquid chromatography. Brain Res 305 (1984) 209-219.

10. Kissane JM, Robbins E. The fluorimetric measurement of deoxyribonucleic acid in animal tissues with special reference to the central nervous system. J Biol Chem 233 (1958) 184-188.

11. Korr H. Proliferation of different cell types in the brain. Adv Anat Embryol Cell Biol 61 (1980) 61-72.

12. Kramer CG, Ott MG, Fulkerson JE, Hicks N. Health of workers exposed to 1,1,1-trichloroethane: A matchedpair study. Arch Environ Health 33 (1978) 331-342.

13. Kubic VL, Anders MW. Metabolism of dihalomethanes to carbon monoxide: 11 In vitro studies. Drug Metab Dispos 3 (1975) 104-112.

14. Lowry OH, Rosebrough NJ, Farr AL, Randall RJ. Protein measurement with the folin phenol reagent. J Biol Chem 193 (1951) 265-275.

15. Mann DMA, Yates PO. A quantitative study of the glia of the purkinje cell layer of the cerebellum in mammals. Neuropathol Appl Neurobiol 5 (1979) 71-76.

16. Marietta MP, Vesell ES, Hartman RD, Weisz J, Dvorchik BH. Characterization of cytochrome P-450-dependent aminopyrine $\mathrm{N}$-demethylase in rat brain: Comparison with hepatic aminopyrine $\mathrm{N}$-demethylation. $\mathrm{J}$ Pharmacol Exp Ther 208 (1979) 271-279.

17. Maroni M, Bulgheroni C, Cassitto MG, Merluzzi F, Gilioli R, Foa' V. A clinical, neurophysiological and behavioral study of female workers exposed to 1,1,1trichloroethane. Scand J Work Environ Health 3 (1977)
$16-22$

18. McCarthy TB, Jones RD. Industrial gassing poisonings due to trichlorethylene, perchlorethylene, and 1-1-1 trichloroethane, 1961 - 80. Br J Ind Med 40 (1983) 450455.

19. McKenna MJ, Zempel JA. The dose-dependent metabolism of $\left({ }^{14} \mathrm{C}\right)$ methylene chloride following oral administration to rats. Food Cosmet Toxicol 19 (1981) 73-78.

20. McKenna MJ, Zempel JA, Braun WH. The pharmacokinetics of inhaled methylene chloride in rats. Toxicol Appl Pharmacol 65 (1982) 1-10.

21. Pegg DG, Zempel JA, Braun WH, Watanabe PG. Disposition of tetrachloro $\left({ }^{14} \mathrm{C}\right)$ ethylene following oral and inhalation exposure in rats. Toxicol Appl Pharmacol 51 (1979) 465-474.

22. Prendergast JA, Jones RA, Jenkins LJ Jr, Siegel J. Effects on experimental animals of long-term inhalation of trichloroethylene, carbon tetrachloride, 1,1,1-trichloroethane, dichlorodifluoromethane, and 1,1-dichloroethylene. Toxicol Appl Pharmacol 10 (1967) 270-289.

23. Rosengren LE, Aurell A, Kjellstrand P, Haglid KG. Astrogliosis in the cerebral cortex of gerbils after long-term exposure to 1,1,1-trichloroethane. Scand J Work Environ Health 11 (1985) 447--456.

24. Rosengren LE, Kjellstrand P, Aurell A, Haglid KG. Irreversible effects of dichloromethane on the brain after long term exposure: A quantitative study of DNA and the glial cell marker proteins S-100 and GFA. Br J Ind Med 43 (1986) 291-299.

25. Rosengren LE, Kjellstrand P, Aurell A, Haglid KG. Irreversible effects of xylene on the brain after long term exposure: A quantitative study of DNA and the glial cell marker proteins S-100 and GFA. Neuro Toxicol 7 (1986) $121-136$.

26. Rosengren LE, Kjellstrand P, Haglid KG. Tetrachloroethylene: Levels of DNA and S-100 in the gerbil CNS after chronic exposure. Neurobehav Toxicol Teratology 8 (1986) 201-206.

27. Rosengren LE, Wronski A, Briving C, Haglid KG. Long lasting changes in gerbil brain after chronic ethanol exposure: A quantitative study of the glial cell marker S-100 and DNA. Alcoholism 9 (1985) 109-113.

28. Rowe VK, McCollister DD, Spencer HG, Adams EM, Irish DD. Vapor toxicity of tetrachloroethylene for laboratory animals and human subjects. Arch Ind Hyg Occup Med 5 (1952) 566-579.

29. Sato A, Nakajima T. A structure-activity relationship of some chlorinated hydrocarbons. Arch Environ Health 34 (1979) 69-75.

30. Schumann AM, Fox TR, Watanabe PG. $\left({ }^{14} \mathrm{C}\right)$ Methyl chloroform (1,1,1-trichloroethane): Pharmacokinetics in rats and mice following inhalation exposure. Toxicol Appl Pharmacol 62 (1982) 390-401.

31. Schumann AM, Fox TR, Watanabe PG. A comparison of the fate of inhaled methyl chloroform (1,1,1-trichloroethane) following single or repeated exposure in rats and mice. Fundam Appl Toxicol 2 (1982) 27-32.

32. Schumann AM, Quast JF, Watanabe PG. The pharmacokinetics and macromolecular interactions of perchloroethylene in mice and rats as related oncogenicity. Toxicol Appl Pharmacol 55 (1980) 207-219.

33. Stewart RD. The toxicology of 1,1,1-trichloroethane. Ann Occup Hyg 11 (1968) 71-79.

34. Stewart RD, Baretto ED, Dodd HC, Torkelsson TR. Experimental human exposure to tetrachloroethylene. Arch Environ Health 20 (1970) 224-229.

35. Stewart RD, Fisher TN, Hosko MJ, Peterson JE, Baretta ED, Dodd HC. Experimental human exposure to methylene chloride. Arch Environ Health 25 (1972) $342-348$.

36. Stewart RD, Gay HH, Erley DS, Hake CL, Schaffer AW. Human exposure to 1,1,1-trichloroethane vapor: Relationship of expired air and blood concentrations to 
exposure and toxicity. Am Ind Hyg Assoc J 22 (1961) $252-262$.

37. Stewart RD, Gay HH, Schaffer AW, Erley DS, Rowe VK. Experimental human exposure to methyl chloroform vapor. Arch Environ Health 19 (1969) 467-472.

38. Stewart RD, Hake CL. Paint-remover hazard. J Am Med Assoc 235 (1976) 398-401.

39. von Hanke C, Ruppe K, Otto J. Untersuchungsergebnisse zur toxischen Wirkung von Dichloromethane bei Fussbodenlegern. Z Gesamte Hyg ihre Grenzgeb 20 (1974) 81-84.

40. von Weiss G. Toxische Enzephalose beim beruflichen
Umgang mit Methylenchlorid. Zentralbl Arbeitsmed Arbeitsschutz 17 (1967) 282-285.

41. Westerberg E, Larsson L. The use of automated headspace gas chromatography for determination of $1,1,1$ trichloroethane in rat blood and brain tissue. Int $\mathrm{J}$ Environ Anal Chem 12 (1982) 233-239.

42. Winneke G, Fodor GG. Dichloromethane produces narcotic effect. Int J Occup Health Saf 45 (1976) 34-49.

Received for publication: 20 March 1987 